\title{
The Informal Food Sector and Cohabitation with Supermarkets in Windhoek, Namibia
}

\section{Ndeyapo Nickanor ${ }^{1}$ Jonathan Crush $^{2,3} \cdot$ Lawrence Kazembe $^{4}$}

Published online: 22 June 2019

(C) Springer Nature B.V. 2019

\begin{abstract}
Much of the literature on urban food systems has focused on supermarket expansion and their ability to reach urban consumers. However, the current pace of urbanisation and rising urban poverty has been accompanied by a major upsurge in informality and a growing role for the informal food sector. One of the persistent arguments in the supermarkets literature is that the expansion of modern retail undermines the informal food sector. Critics of this argument suggest that there are two conditions under which this may not occur: first, when there is spatial differentiation with supermarkets servicing higher income areas and the informal sector targeting low-income areas. And second, when there is market segmentation when the formal and informal sectors focus on the sale of different product types. This paper examines the case of Windhoek, Namibia, which has undergone a major supermarket revolution in the last two decades. It suggests that the informal food sector is vibrant and growing but that neither explanation fully accounts for its resilience and survival. Instead, by examining the strategies of vendors, it suggests the concept of cohabitation as an alternative explanation. Cohabitation may be a pertinent factor in other supermarket cities as well.
\end{abstract}

Keywords Informal food sector · Urban food system · Supermarket revolution · Food security · Urbanisation · Windhoek

\section{Introduction}

Rapid urbanisation in Africa has been accompanied by a major transformation in national and local food systems (Battersby and Watson 2019; Crush and Battersby

Jonathan Crush

jcrush@balsillieschool.ca

1 Faculty of Science, University of Namibia, Windhoek, Namibia

2 Balsillie School of International Affairs, 67 Erb St West, Waterloo, Ontario N2L 6C2, Canada

3 University of Western Cape, Cape Town, South Africa

4 Department of Statistics and Population Studies, University of Namibia, Windhoek, Namibia 
2016; Frayne et al. 2018; Tacoli 2017). Thomas Reardon and colleagues were the first to argue that this transformation was being driven by a "supermarket revolution" which involved progressively greater control over food supply and marketing by international and local supermarket chains (Reardon and Berdegué 2002; Reardon et al. 2003, 2004; Weatherspoon and Reardon 2003). These proponents of the supermarket revolution model argue that the revolution has occurred in "stages" or "waves" and that the domination of supermarkets over food systems in the global North will inevitably diffuse to Africa. The first wave was in larger cities and richer countries in North America, Europe, some Latin American countries and South Africa in the 1980s and 1990s. The second took place from the mid-1990s onwards in Southeast Asia, Central America and Mexico. The third occurred in the late 1990s and early 2000s in countries such as China, Vietnam, India and Russia. Africa outside South Africa is seen as part of the fourth wave of the revolution (Altenberg et al. 2016; Dakora 2012).

According to the model, the spread and domination of supermarkets is not only inevitable but means that other forms of food retail come under severe competitive pressure (Reardon and Hopkins 2006). Absent protective measures, supermarkets will eventually displace and eliminate the informal food sector, destroying livelihoods and increasing unemployment in the process. Kennedy et al. (2004, p. 1), for example, argue that "competition for a market share of food purchase tends to intensify with entry into the system of ... large multinational fast food and supermarket chains. The losers tend to be small local agents and traditional food markets." Reardon and Gulati (2008, p. 17) similarly assert that "the mirror image of the spread of supermarkets is the decline of the traditional retail sector".

One of the reasons for the domination of supermarkets is their ability to utilise economies of scale and undercut small retailers by offering lower prices to consumers (Minten et al. 2010). Minten and Reardon (2008) review food pricing evidence from several countries and argue that supermarkets have an immediate price advantage for processed food and that over time they begin to charge lower prices than traditional markets for fresh produce as well. Banwell et al. (2012) suggest that in Thailand, supermarkets are driving out small fresh produce providers over time, while Gorton et al. (2011) found that consumers prefer supermarkets over wet markets on virtually every indicator and that the competitive advantage of the latter in the supply of fresh produce is in decline (see also Kelly et al. 2015). In Zambia, Miller (2008, p. 21) notes that "informal sector producers have often experienced displacement in local markets for basic foodstuffs". Louw et al. (2007, p. 25) argue that in South Africa, there is "strong evidence that the informal sector is losing significant market share as a result of the encroachment of supermarkets into the territories occupied by the informal sector".

In this paper, we test one of the central tenets of the supermarket revolution model, i.e. that the spread of supermarkets and their local, regional and global supply chains necessarily has a destructive effect on pre-existing forms of small-scale and/or informal markets and vendors and severely inhibits the growth of the informal food sector. Because the evidence for informal food sector survival, resilience and growth is ambiguous and contradictory, it may well be that the answer is context-specific. In that event, further case studies are needed to build a more general knowledge base from which to derive policy lessons for the equitable governance of urban food systems in general and the informal food sector in particular (Skinner and Haysom 2017; Skinner and Watson 2018; Skinner 2019). What makes the Windhoek (Namibia) case relevant 
is the overwhelming presence of foreign-owned supermarkets throughout the city and, simultaneously, an important informal food sector. Neither of the current models of informal sector fully explain the Windhoek situation.

The first section of the paper examines various empirical studies from around the world that call the inevitable destruction argument into question. The next section of the paper reviews two competing explanations for the survival and growth of the informal food sector in cities of the Global South. The first focuses on spatial differentiation, in which supermarkets target higher income parts of the city, leaving low-income areas to the informal sector. The second is market segmentation where the informal food sector and supermarkets provide different products and are therefore not in direct competition. Neither of these models fully captures the situation in Windhoek, requiring an alternative explanation. The next section describes the simultaneous expansion of both supermarkets and the informal food sector in Windhoek. The paper then presents the results of a 2016 consumer survey in Windhoek and shows that most households patronise both food sources. This implies the existence of robust competition between formal and informal food retail. How informal food vendors perceive and deal with supermarket competition is then discussed on the basis of evidence from in-depth qualitative interviews. We therefore propose an alternate cohabitation explanation to account for the resilience of the informal food sector in Windhoek which provides a better depiction of informal food sector survival than either spatial differentiation of market segmentation.

\section{Inside the Revolution}

Critics of the supermarket revolution in Africa have questioned its supposed inevitability, the lack of attention to the obstacles confronting supermarket supply chains, and the potentially disruptive impact of supermarkets on traditional forms of retail (Abrahams 2010, 2011; Humphrey 2007; Vink 2013; Crush and Frayne 2018; Skinner 2019). Minten (2008, p. 769), for example, argues that supermarkets target higher income rather than poor consumers in Madagascar and therefore "there would seem to be little scope for market share growth for global retail chains in this environment". Madevu et al. (2007) found that supermarkets in Tshwane, South Africa, have had a major impact on corner stores and greengrocers but that the informal sector has been more resilient. They suggest that supermarkets dominate high-income areas and informal vendors continue to dominate low-income areas. Abrahams (2007) makes a similar argument about informal sector resilience in Johannesburg.

The argument that supermarkets and the informal food sector are spatially differentiated and serve clientele in different parts of the city is a plausible explanation for why the informal food sector might survive and thrive, provided that supermarkets stay out of, and remain far from, low-income areas of a city. Berger and van Helvoirt (2018, p. 12), for example, argue that in Nairobi, Kenya, supermarkets "increase food access mainly for the higher income - and already food secure - consumers in the city, while the poor and food insecure are largely excluded from patronizing supermarkets and rely on the informal market". However, this argument for spatial differentiation starts to break down if supermarkets start to target lower-income consumers in poorer areas of the city, as has been happening in many South African cities (Battersby and Peyton 
2016; Caesar and Crush 2016). A snapshot of the food purchasing habits of over 6000 households in low-income neighbourhoods in 11 African cities conducted by AFSUN in 2008-2009 found that nearly $80 \%$ shopped at supermarkets compared with $70 \%$ that patronised the informal food sector. At the very least, this suggests that many lowincome households patronise both (Crush and Frayne 2018). There was considerable inter-city variation in levels of supermarket patronage, however, from a high of $97 \%$ in Msunduzi and Windhoek to a low of $16 \%$ in Lusaka. The greater the overall level of supermarket patronage, the lower the level of informal sector patronage (and viceversa).

Empirical evidence from other parts of the world suggests alternative explanations for the resilience of informal and small-scale retail in the face of rapid supermarket expansion. In Brazil, for example, Farina et al. (2005, p. 134) show that "different formats of retail stores live together in the Brazilian market, compete for consumer preference and, at the same time, complement each other". While small retailers are more expensive, consumers are willing to pay more for the convenience they offer and also benefit from the lower transport costs involved in accessing their services. In Taiwan, Huang et al. (2015) demonstrate that the social interactions offered by informal vendors are critical for customer satisfaction and create a positive incentive for patronage. Schipmann and Qaim (2011, p. 359) compare supermarkets and wet markets in Thailand and find that "the rapid expansion of modern retailers seems to be more associated with the growth of high-quality, differentiated market segments rather than a direct competition for traditional market shares". Similarly, Si et al. (2016) find that in China, wet markets are the preferred source of fresh produce while supermarkets dominate the market for processed foods.

The concept of differentiated market segments can thus also help explain why supermarkets will not necessarily undermine the informal food sector. In addition, Suryadarma et al. (2010) argue in Indonesia that the decline of numbers and profitability of traditional market retailers should not be automatically attributed to the rapid expansion of supermarkets. Rather, the main causes of decline are that "traditional markets are plagued with internal problems and face increasingly bitter competition from street vendors" (Suryadarma et al. 2010, p. 79). This observation highlights an important point with general applicability: the informal food sector is not an undifferentiated whole and competition between different types of food vendor need to be factored into any explanation of decline.

In the African case, the disintegration of spatial differentiation accompanying supermarket intrusion into low-income areas does not automatically mean the end of differentiated market segmentation. Peyton et al. (2015, p. 26) suggest that, in Cape Town, supermarket expansion is "often incompatible with the consumption strategies of the poorest households". Poor households patronise informal vendors because they can buy food on credit, purchase small quantities on a daily basis, and access street vendors and spazas on foot within residential areas and at transportation hubs (Battersby et al. 2016). Formal sector wholesalers and produce markets are major suppliers of products to the informal sector, but mobile vendors also source produce at supermarkets and cluster near supermarkets in order to try and take advantage of their customer base. How effective these strategies are in the long run and whether the informal food sector is able to survive and grow are unresolved questions. In addition, competition with supermarkets is far from being the only challenge facing informal 
food sector businesses. The national and municipal policy environment is a key enabler or inhibitor. While policies oscillate between "benign neglect" and "active destruction" (Crush et al. 2017), examples of active support and encouragement are rare (Skinner 2019).

\section{Informal Food in Windhoek}

Nickanor et al. (2017) give a detailed account of the Namibian supermarket revolution and, in particular, the expansion of South African-owned supermarket chains in Windhoek. Recently, there are 25 South African-owned supermarkets from all of the major South African chains, as well as one major Namibian-owned chain (Woermann Brock) (Table 1). There are also a number of independently owned local supermarkets in the city. All of the South African-owned supermarkets are directly accountable to head offices in South Africa. SPAR is the only South African company that operates a franchise model and therefore has local franchise owners. Figure 1 shows the spatial distribution of supermarkets throughout the city.

Although there is at least one supermarket in every constituency, they tend to be concentrated in wealthier areas of the city. Table 2, for example, shows that 25 of the corporate and independent supermarkets are located in Windhoek East and Windhoek West where the majority of the city's middle-class and high-income earners reside. Although Woermann Brock, Shoprite (through its USave subsidiary), and independent supermarkets are located closer to the poorer northern informal settlements of the city, there are very few supermarkets located within these areas. Table 2 also provides an approximation of the ratio of supermarkets to population (suing data from the most recent census). Windhoek East has a ratio of less than 2000 persons per supermarket, compared with over 40,000 persons per supermarket in the two northern constituencies of Moses Garoeb and Thomas Hainyeko.

Although there have been a number of small-area case studies of Windhoek's informal sector over the years (Amwele 2013; Kambwale et al. 2015; Nickanor

Table 1 Number of supermarkets in Windhoek, 2016

\begin{tabular}{lcr}
\hline & No. & $\%$ \\
\hline South African-owned & & 32.3 \\
Shoprite/Checkers/USave & 10 & 12.9 \\
Pick n Pay & 4 & 12.9 \\
SPAR & 4 & 6.4 \\
Woolworths & 2 & 6.4 \\
Massmart-Walmart (Game) & 2 & 9.7 \\
Fruit \& Veg City (Food Lover's Market) & 3 & 19.4 \\
Namibian-owned & & 100.0 \\
Woermann Brock & 6 & 31 \\
Total & & \\
\hline
\end{tabular}

Source: company annual reports, 2016 


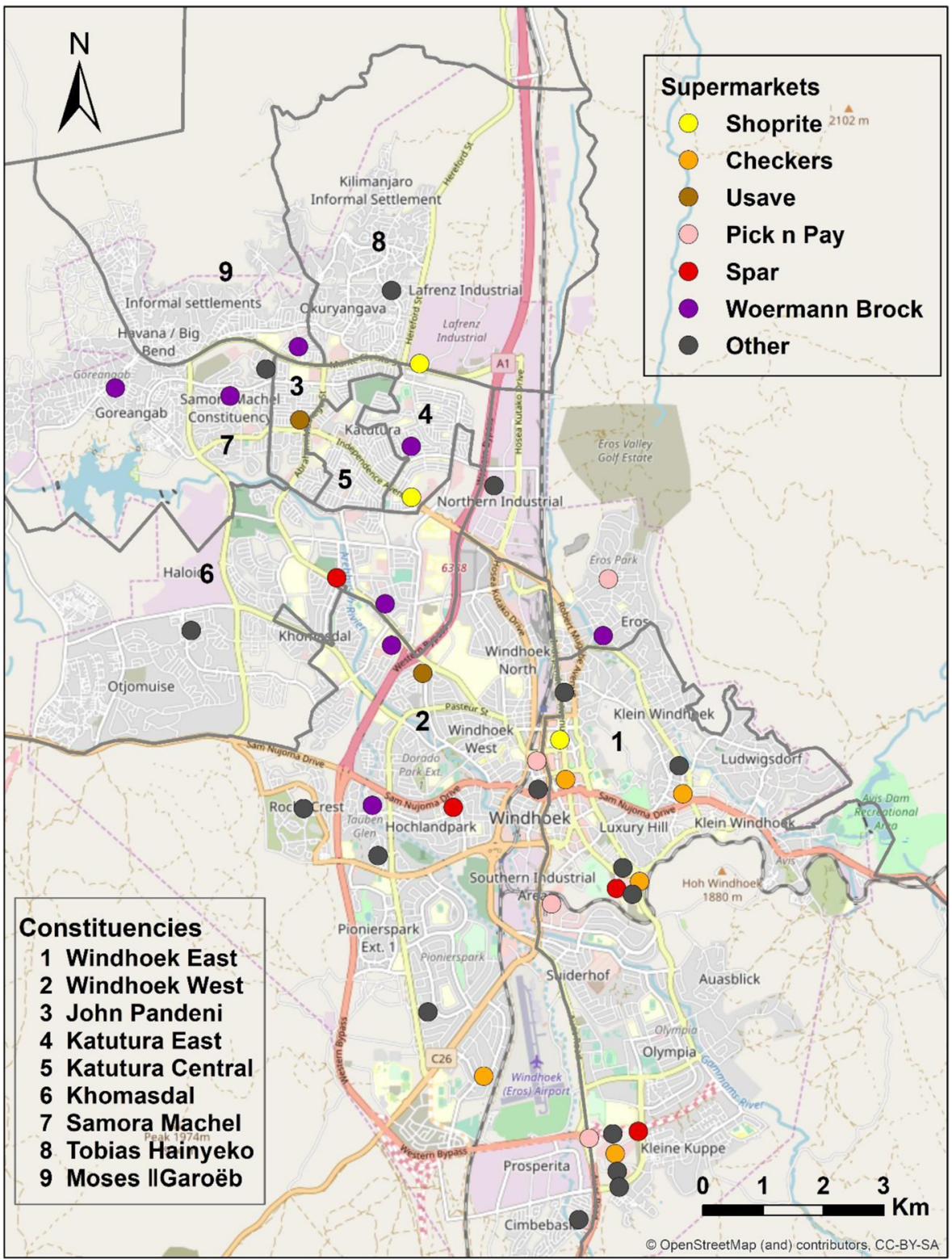

Fig. 1 Spatial distribution of supermarkets

2014; Seibes-Bock 2004), there is no comprehensive census of the informal food sector so the exact numbers and locations are not known. National statistics do indicate rapid informal sector growth. According to the 2016 Namibian Labour Force Survey, twothirds of the employed people in the country were in informal employment $(450,000$ out of 677,000 ). Of these, 238,000 or $53 \%$ were in urban areas (NSA 2017, p. 51). The Khomas Region (in which Windhoek is located) had 93,000 people in informal employment (or 56\% of total employed) of whom 53,000 were male and 43,000 
Table 2 Location of corporate supermarkets by constituency

\begin{tabular}{lcccc}
\hline & Total & \% poor/severely poor* & Population (2011) & Supermarkets per capita \\
\hline Windhoek East & 16 & 0.0 & 25,823 & 1614 \\
Windhoek West & 9 & 0.0 & 53,438 & 5.938 \\
John Pandeni & 1 & 4.3 & 22,359 & 22,359 \\
Katutura East & 3 & 4.5 & 21,564 & 7188 \\
Katutura Central & 1 & 8.3 & 26,904 & 26,904 \\
Khomasdal & 3 & 14.7 & 35,832 & 11,944 \\
Samora Machel & 3 & 37.5 & 49,178 & 16,393 \\
Tobias Hainyeko & 1 & 36.1 & 45,912 & 45,192 \\
Moses Garoëb & 1 & 77.8 & 41,988 & 41,988 \\
Total & 38 & 100.0 & 322,998 & 8500 \\
\hline
\end{tabular}

*Based on 2016 NSA-NHIES poverty indicators

female. A sectoral breakdown is not available for Khomas Region, although in the country as a whole 44,000 were employed in wholesale and retail trade (NSA 2017, p. 51). This makes it the third highest employer after private households $(53,000)$ and construction (47,000). The recent Namibia Informal Economy case study interviewed 4506 "own-account" enterprises around the country, of whom 1084 were in the urban part of Khomas region and only $20 \%$ were registered with the City (Government of Namibia 2017). Nationally, 54\% of enterprises were engaged in wholesale and retail trade (including fruit and vegetable selling, kapana, and other types of food service activities). The majority (62\%) of these enterprises were established between 2010 and 2016. Close to half, $47 \%$, had been operating for more than 5 years.

The informal food sector is concentrated spatially in the central and northern parts of Windhoek and consists of four main types of vendor: (a) street food vending stands, (b) mobile vendors, (c) tuck shops (spazas) and (d) market stalls in the city's designated open markets. Street food vending stands are located beside and inside homes and near work places (especially government offices and hospitals), at loading zones for long distance bus routes, and close to open markets. Some stalls are more permanent (including mobile caravans) while others are makeshift structures covered with umbrellas or cardboard boxes, or just a table covered with a shade net. Clusters of vendors have been officially recognised by the City and are designated as "informal markets". Informal street vendors sell fruit and vegetables, matangara (cooked offal), traditional meals (with mopane worms and dried spinach), fresh or cooked chicken, and home cooked meals prepared on site or at home, including mahangu pap, rice, pasta, potato salad, chicken stew, beef stew, kapana, oshinghali (mashed cow peas), macaroni salad, butternut and cabbage. Some street vendors also sell "junk food" including crisps/chips, sweets/candies and sugary cool drinks/pop.

Mobile vendors are primarily women who follow construction sites and sell cooked food to workers such as beef stew, matangara, vetkoekies, mahangu pap and oshikundu. Some mobile vendors also sell produce from the back of vehicles. Some individual mobile vendors sell products such as fish from door-to-door. Tuck shops are small fixed tin structures located mainly in the informal settlements and selling a range 
of processed snacks and fresh produce. Scattered amongst the tuck shops are numerous informal liquor outlets (or cuca shops).

Finally, the City of Windhoek has attempted to control the spatial spread of informal food vending by constructing 16 "open markets" across the city. Most of the open markets are closer to low-income areas of the city and have roofs, fixed stalls and services such as electricity and sanitation. Informal vendors pay a fee to a management board in exchange for a stall or a space. In these open markets, traders sell products such as vegetables, dry food ingredients, cooked food, kapana (cooked meat) and fresh meat. Some also have informal clothing, shoe repair and hairdressing stalls.

\section{Household Food Sourcing}

This section of the paper on household food sourcing draws on data from a city-wide household food security survey conducted by the Department of Statistics and Population Studies at the University of Namibia through the African Food Security Urban Network (AFSUN) and Hungry Cities Partnership (HCP) in 2016. The survey instrument was developed by AFSUN and HCP and mounted on tablets through a modified computer-assisted personal interviewing open data toolkit (ODK). The survey interviewed a total of 863 households, drawn from all ten constituencies of the city, using a two-stage cluster sampling design. First, a total of 35 primary sampling units (PSU) were randomly selected with probability proportional to size (PPS). The PSUs were selected from a master frame developed and demarcated for the 2011 Population and Housing Census. The second stage involved systematic sampling of 25 households in each of the selected PSUs. In each household, the head or their representative was interviewed. The survey collected data on household demography and economics, levels of food security, the type and location of food sources, and the purchasing strategies of households. In addition, in-depth interviews were conducted with a selection of informal vendors of different types with a view to understanding their perceptions of the food system and competition from the large number of supermarkets in the city, including patronage of supermarkets and informal vendors. Second, 20 indepth interviews were conducted with informal vendors selling food at different locations in different formats.

The survey found that most households in Windhoek obtain much of their food by purchasing it from formal and informal retail outlets. Urban agriculture is very limited, practiced by less than $5 \%$ of households across the city and even fewer in the informal settlements. Poorer households continue to receive informal food transfers from rural areas but this has declined in recent years (Frayne 2005). In the survey, only $11 \%$ of households in informal housing and $12 \%$ in formal housing said they receive food from relatives in the rural areas. As Fig. 2 shows, the overwhelming majority of all households in both formal (99\%) and informal (94\%) housing said they source food from supermarkets. Supermarket domination is thus clearly evident in overall household food patronage. Despite the fact that supermarkets are more distant from the informal areas of the city, patronage is almost as high for poorer informal households as it is for middle and higher income households in formal housing.

The second most important food source is the open markets, where $56 \%$ of households in informal housing and $42 \%$ of households in formal housing obtain some 


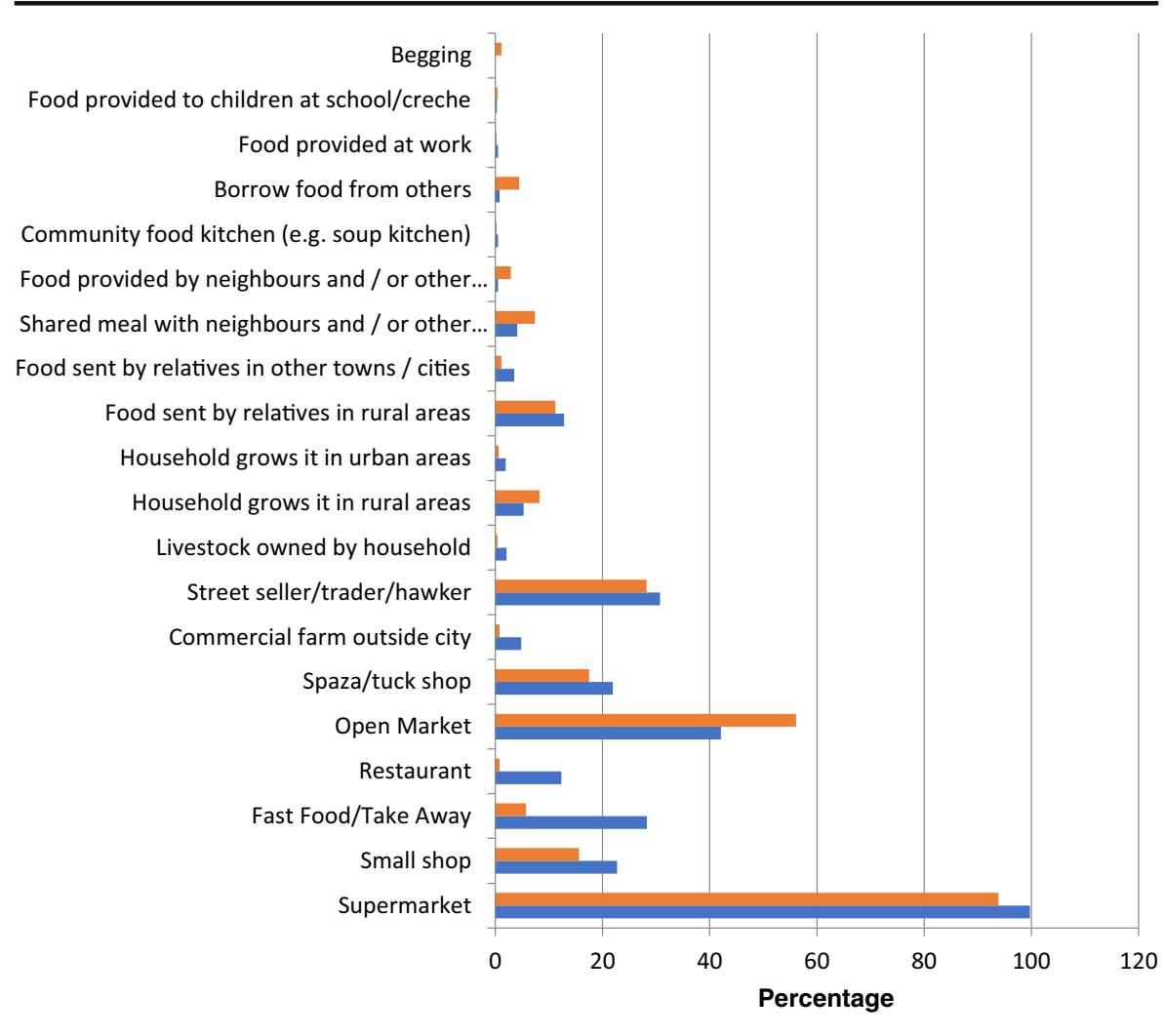

Informal armal

Fig. 2 Household sources of food

of their food. Third are street sellers/traders/hawkers (which includes those in informal markets) at $28 \%$ and $31 \%$ respectively. Finally, tuck shops are patronised by $18 \%$ of informal and $22 \%$ of formal housing households. In other words, while supermarkets are patronised by almost all households in Windhoek, the informal food sector does

Table 3 Frequency of sourcing food across retail outlets (\%)

\begin{tabular}{|c|c|c|c|c|c|c|}
\hline & \multirow{2}{*}{$\begin{array}{l}\% \text { of households } \\
\text { who patronise outlet }\end{array}$} & \multicolumn{5}{|c|}{ Frequency of purchase from the source $(\%)$} \\
\hline & & $\begin{array}{l}\text { At least } \\
5 \text { days a week }\end{array}$ & $\begin{array}{l}\text { At least } \\
\text { once } \\
\text { a week }\end{array}$ & $\begin{array}{l}\text { At least once } \\
\text { a month }\end{array}$ & $\begin{array}{l}\text { At least once } \\
\text { in } 6 \text { months }\end{array}$ & $\begin{array}{l}\text { At least once } \\
\text { a year }\end{array}$ \\
\hline Supermarket & 96.5 & 4.5 & 16.5 & 65.7 & 12.4 & 0.8 \\
\hline Open Market & 49.8 & 17.6 & 46.2 & 19.5 & 16.2 & 0.5 \\
\hline Street Vendors & 29.2 & 49.8 & 33.7 & 6.8 & 9.6 & 0.0 \\
\hline $\begin{array}{l}\text { Spaza/tuck } \\
\text { shop }\end{array}$ & 19.4 & 50.9 & 41.2 & 7.3 & 0.6 & 0.0 \\
\hline
\end{tabular}


play an important role in the food sourcing strategies of many households, and those in the city's informal settlements in particular (Crush et al. 2019).

The patterns of patronage of supermarkets and informal vendors varies considerably, however. Table 3 shows that two-thirds of all households shop at supermarkets once per month, and only $20 \%$ do so more frequently. In stark contrast to this pattern of infrequent supermarket purchasing, are the patronage patterns of the informal food sector. For example, vendors in the open markets are patronised for food on a weekly or daily basis by nearly two-thirds of households. The equivalent figure for street vendors is even higher at $83 \%$ and for tuck shops at $92 \%$. Indeed, both street vendors and tuck shops are patronised daily by around half of all households who patronise them. What

Table 4 Patronage patterns for individual food items

\begin{tabular}{|c|c|c|}
\hline & $\%$ normally purchasing at supermarkets & $\%$ normally purchasing at other outlets \\
\hline \multicolumn{3}{|l|}{ Staples } \\
\hline Maize meal & 96.0 & 4.0 \\
\hline Bread & 53.5 & 46.5 \\
\hline Rice & 99.4 & 0.6 \\
\hline Pasta & 99.6 & 0.4 \\
\hline \multicolumn{3}{|l|}{ Fresh produce } \\
\hline Meat & 61.1 & 38.9 \\
\hline Vegetables & 77.5 & 22.5 \\
\hline Fish & 46.0 & 54.0 \\
\hline Milk & 96.9 & 3.1 \\
\hline Eggs & 93.1 & 6.9 \\
\hline Fruit & 91.1 & 8.9 \\
\hline Offal & 38.1 & 61.9 \\
\hline Chicken & 84.5 & 15.5 \\
\hline \multicolumn{3}{|l|}{ Frozen produce } \\
\hline Chicken & 95.7 & 4.3 \\
\hline Meat & 93.3 & 6.7 \\
\hline Fish & 80.0 & 20.0 \\
\hline \multicolumn{3}{|l|}{ Cooked food } \\
\hline Pies/vetkoek & 53.0 & 47.0 \\
\hline Meat & 51.1 & 48.9 \\
\hline Chicken & 62.5 & 37.5 \\
\hline Fish & 64.0 & 36.0 \\
\hline \multicolumn{3}{|l|}{ Processed food } \\
\hline Cooking oil & 94.6 & 5.4 \\
\hline Sugar & 94.7 & 5.3 \\
\hline Tea/coffee & 96.8 & 3.2 \\
\hline Butter/margarine & 99.6 & 0.4 \\
\hline Pop/soda/cooldrinks & 81.2 & 19.8 \\
\hline Fruit juice & 97.7 & 2.3 \\
\hline Sour milk/omaere & 95.4 & 4.6 \\
\hline Snacks (crisps, etc.) & 66.3 & 32.7 \\
\hline Sweets/chocolate & 57.0 & 43.0 \\
\hline Canned vegetables & 100.0 & 0.0 \\
\hline Canned meat & 95.3 & 4.7 \\
\hline Canned fruit & 100.0 & 0.0 \\
\hline
\end{tabular}


these very different formal versus informal patronage frequencies might suggest is that supermarkets and the informal sector are serving very different food needs.

The Hungry Cities Food Purchases Matrix provides data on what foods are normally purchased at which outlets (Crush and McCordic 2017) and which products are bought at each. Table 4 records whether the preferred outlet for each food item is a supermarket or other source (including open markets, street vendors, tuck shops, and small formal shops such as butcheries and bakeries). Clear differences emerge for a number of individual foodstuffs. Over $90 \%$ of households purchase their cereal staples at supermarkets. This is consistent with the tendency of many households to patronise supermarkets on a monthly basis since these staples are marketed and bought in bulk. Bread is the only exception to this pattern of supermarket domination, where supermarkets share the market with open market vendors, formal sector bakeries, and small shops. Supermarkets clearly dominate the purchasing of frozen and fresh foods. However, other sources have a significant market share of offal (62\%), fish (54\%), meat (39\%), and vegetables (23\%). They also share the market for junk food and cooked food.

\section{Food Vendors on Competition}

The household survey suggests that supermarkets dominate sales of some products but that there are also areas of significant competition for market share between the formal and informal food sectors, particularly for fresh produce, cooked food, and processed junk food. The sale of traditional and wild foods (both cooked or uncooked) is outside the realm of direct competition since supermarkets generally do not stock these products. This section of the paper is based on the in-depth interviews with informal food vendors and addresses the question of whether they perceive supermarkets as a threat to their businesses and livelihoods. Some vendors certainly felt that competition from supermarkets was having a negative impact through the loss of customers, and declining revenue and profits:

I do not really feel happy about the ever-growing supermarkets in our area. These shops are providing competition for me and my profit has decreased over the past months. Here we are only remaining with those customers that are not able to go buy at these shops or we can only get customers after hours when the shops are closed (Interview No. 8).

Competition from supermarkets is always there. I can give you an example of stuff that can go without selling if there is a special in supermarkets. My milk I sell at N\$19.50 but will reduce whether there is a sale in town or not. Like in shops now, it is N\$13 so I don’t do business like I always do (Interview No. 9).

It is not a good thing at all, because us that are selling in streets near these shops are losing customers. Yes, they are giving me competition. The supermarkets 
have affected my business in a way that if my prices are high, then people just go buy in supermarkets instead (Interview No. 17).

It is a bad thing. Most of our customers are now going to these shops instead of buying from the stalls here. Now we are no longer getting customers in the open market like in the past (Interview No. 18).

Another noted that the loss of customers to supermarkets meant that they faced problems with spoilage of unsold goods. Alternatively, they reduced their prices simply to avoid financial loss:

People from this area are always going to shop from supermarkets if they find out that I do not sell the goods that they are looking for. These shops are giving us difficulties in selling our goods sometimes. Most of the time people buy from the supermarkets on their way from work and end up not buying from our stands. I throw away all foods that I am not able to sell when they are spoiled. Sometimes I reduce the prices of the foods that I am not able to sell over a long period to avoid making a loss for that particular month (Interview No. 11).

However, other vendors either did not see supermarkets as a threat or even relevant to their operations. One reason was that their customer base in the immediate vicinity was large and supermarkets were some distance away:

The increase in supermarkets does not affect my business because there are a lot of people here. Like for example, these 20 loaves of bread will be stocked up today, when people are knocking off work, and as they pass by on their way home (Interview No. 3).

These foods are in demand in this area and the shops from where people can buy their daily needs are far away. People in this area always find it convenient to buy from the stalls alongside the road (Interview No. 14).

These supermarkets do not give me competition since they operate from far. My business is not directly affected, because I am just targeting school children and households in this street and nearby streets (Interview No. 7).

Others noted that they were able to compete because they were meeting niche consumer needs and selling food not available in supermarkets. These included traditional products and cooked foods: 
The products I sell are traditional dry food (which varies depending on the season), mahangu flour, beans, chilli, salt, sorghum flour, omutete, ombidi, spices, mopane worms, dry fish, moringa, capenta. You need to have stock and it's not easy to source traditional food; it's not as if you can find them in a market (Interview No. 2).

Supermarkets are not giving me competition at all, since I am only selling cooked (food) and those that are not able to buy in supermarkets buy their lunch from me (Interview No. 16).

Others thought that the presence of supermarkets was a good thing for their businesses, in part because they brought them additional customers in the form of supermarket and other employees:

It is actually a good thing that there are more supermarkets now. The supermarkets are not giving me any competition at all, even their own employees come buy from me. If there was a competition, I would not be having supermarkets employees as my customers. They don't affect my operations (Interview No.13).

I get more customers here compared to the area where I was operating from in January. Most people that are working in these shops and those that are working at construction sites nearby always come to buy from here since most of them complain of fast food prices in the shops located in the malls (Interview No. 13)

These comments help explain why some street vendors locate their stalls close to supermarkets rather than, as might be expected, as far away as possible.

A striking feature of informal food vending in Windhoek is price sensitivity. Markups are small and vendors are constantly on the look-out for products with resale potential. Many vendors strategically source produce at supermarkets, and take advantage of sales and price competition between different supermarkets:

I buy mainly in Shoprite, Pick n Pay, Checkers and sometimes in Spar because I check where there is a sale. The type of food I buy is mainly macaroni, rice, cooking oil and meat (Interview No 1).

It is actually a good thing that there are more supermarkets now around Windhoek. This allows me to choose where I should go buy my products depending on the cost of the goods (Interview No. 7). 
It is good that there are more supermarkets now. This gives us an opportunity to choose where we want to buy from. These supermarkets are not a competition to me. My only competitors are the unregistered vendors that come sell from here. Like at this braai site, there were only supposed to be three vendors (Interview No. 12).

Others mix supermarket purchase with sourcing from other suppliers including small formal outlets such as butcheries, open markets, and even other street vendors:

I source my products from Pick n Pay in Katutura, Spar in Khomasdahl, fish from Mama Fresh, millet from my mother in the north (50kg every two a half months). Free range chicken is from Single Quarters. Pick n Pay normally has fresh and clean products unlike Woermann Brock and Shoprite. You can also find most products in Pick n Pay (Interview No. 5).

Boerwors and meat I buy from Rand St Butchery in Khomasdal. I buy cool drinks from Metro or anywhere there is a sale. Coffee and tea from Pick n Pay, Spar or Metro depending on the price. These shops are cheaper and they are always having food items on sale (Interview No. 12).

It is cheaper to buy in bulk than buying single items. I buy my potatoes from a vendor in Okuryangava area opposite the clinic. They are cheaper there and big compared to supermarkets. I buy my Russians (sausages) from a shop in Southern Industrial area. Russians are cheaper there. I buy Oros and sweets from Metro. It is close by and they are cheaper compared to buying from Food Lover's Market or Checkers (Interview No. 13).

I buy meat and cabbage from vendors in Monte Cristo road or in the open market. It is cheaper to buy from them than supermarkets. I buy macaronic, nik-naks, and sugar for Oshikundu and Otombo from Namica supermarket. I send my children to buy there while I am still here selling. The shop is also cheap. I buy Meme mahangu from Shoprite U-Save and sorghum from the open market in Okuryangava. U-Save and the Open market are also at Stop n Shop area where I buy most of my goods. I buy macaroni, Meme mahangu, sugar, baking flour, yeast, soup, cooking oil. These goods are only found in supermarkets (Interview No. 15).

I only buy top score, 50 kilograms per month. When it is not enough, I add about 25 kilograms in the middle of the month. I also buy tinned fish and this I usually buy from Shoprite and Woermann. I do not buy fruits and vegetables because it is usually just seen as for people who have money. I go to the shop as frequently as I 
have the money to buy the top score and the tinned fish. The longest I take is two weeks to go back there. But for meats I have to do it a lot because we do not have means of refrigerating it (Interview No. 8).

These comments come from a small and non-representative sample of vendors, but they do draw attention to the fact that not all informal food vendors have a negative experience of supermarket expansion. Some are definitely under considerable competitive pressure while others seem able to co-exit with and even take advantage of the presence of supermarkets through selling products not carried by supermarkets, by sourcing products from supermarket sales, by mixing supermarket purchasing with other suppliers, and by tapping the customer base of supermarket patrons and employees.

\section{Conclusion}

Namibia's supermarket revolution has been led by the major South African-owned supermarket chains. The supermarket revolution in Windhoek has not led to the demise of the informal food sector as predicted by some proponents of the model. Informal food retail has continued to grow despite the domination of the food system by supermarkets. High rates of unemployment and continued in-migration to the city's informal settlements mean that the informal sector is a significant livelihood source for many households. Despite the spread of supermarkets into the lower-income areas of Windhoek, they are still largely concentrated in wealthier areas of the city. There are parts of the city, especially in the informal far north where the nearest supermarkets are some distance away and households largely rely on tuck shops, and mobile and fixed vendors for their daily and weekly purchases. However, the situation is extremely fluid as new supermarkets are progressively extending their reach into low-income areas. While the spatial differentiation argument therefore still has some relevance, it is becoming increasingly strained as a sole explanation for the survival of the informal food sector.

A second general explanation for the resilience of the informal food sector is the market segmentation argument in which formal and informal retail meet different consumer demands and needs. Supermarkets have clearly cornered the consumer market for staple grains in Windhoek because of their ability to purchase and market in bulk. They also dominate the market for processed and frozen foods and some fresh produce such as fruit. The vast majority of these products are imported from South Africa and informal vendors find it difficult to compete (Emongor 2009; Nickanor et al. 2017). At the same time, there are product niches - particularly for wild foods, cooked food and cheap meat such as offal - in which the informal sector thrives. However, if there is sufficient demand, supermarkets will certainly target it. For example, offal is increasingly sold in supermarkets located in lower-income areas. There is thus a degree of market segmentation in Windhoek but also areas of intense market competition especially for items such as meat, fish, bread, vegetables, and snacks.

The qualitative interviews with vendors themselves provided insights into a third possible explanation for informal food sector resilience; what we refer to in this paper as cohabitation. That is, informal sector vendors survive, and sometimes thrive, by 
taking advantage of the presence and proximity of supermarkets in at least two ways. First, shopping malls and their constituent supermarkets provide informal vendors with a ready market in the form of their own (often low-paid) employees and supermarket customers who may also patronise informal vendors operating on the doorstep of these outlets. It is a common site in Windhoek to see vendors operating outside supermarkets, selling smaller quantities of goods or different products than those that are available inside. Second, since supermarkets are a primary source of produce for informal vendors for resale in other parts of the city, vendors are extremely sensitive to price competition between supermarket chains, shopping around and taking advantage of any sales on offer at different supermarkets.

Cohabitation is also facilitated by the food governance environment in Windhoek. Government has done little to control the construction of new malls and the expansion of supermarkets in the city. Its policy interventions have focused more on supermarket supply chains in an effort to control the import of South African produce and provide market opportunities for Namibian agriculture (Nickanor et al. 2017). Municipal policy towards the informal food sector has been more interventionist, investing in open markets and recognising the existence of informal markets. At the same time, police actions have regularly been launched against street traders operating in areas which are deemed to be illegitimate trading spaces, including in the CBD. The policy environment is thus broadly supportive of the survival of informal food vending and cohabitation but it is far from unconditional. This speaks to a double standard seen in many African cities where supermarkets can locate and operate at will, while the informal food sector finds itself excluded and under attack for trying to exercise the same rights (Skinner 2019).

Funding Information The survey discussed in this paper was funded by the Open Society Foundation and the Hungry Cities Partnership with support from the Social Sciences and Humanities Research Council of Canada (SSHRC) and the International Development Research Centre (IDRC) International Partnerships for Sustainable Societies (IPaSS) Program. The writing of the paper was made possible by a grant from the Queen Elizabeth Diamond Jubilee Advanced Scholars program.

\section{References}

Abrahams, C. (2007). Globally useful conceptions of alternate food networks in the global south: the case of Johannesburg's urban food supply system. In D. Maye, L. Holloway, \& M. Kneafsey (Eds.), Alternative food geographies: representation and practice (pp. 95-114). Amsterdam: Elsevier.

Abrahams, C. (2010). Transforming the region: supermarkets and the local food economy. African Affairs, $109,115-134$.

Abrahams, C. (2011). Supermarkets and urban value chains: rethinking the developmental mandate. Food Chain, 1, 206-222.

Altenberg, T., Kulke, E., Hampel-Milagrosa, A., Peterskovsky, L., \& Reeg, C. (2016). Making retail modernisation in developing countries inclusive: a development policy perspective (discussion paper 2/2016). Bonn: German Development Institute.

Amwele, H. (2013). An empirical investigation into the factors affecting the performance of SMEs in the retail sector in Windhoek, Namibia. MIB Thesis, Polytechnic of Namibia, Windhoek.

Banwell, C., Dixon, J., Seubsman, S.-A., Pangsap, S., Kelly, M., \& Sleigh, A. (2012). Evolving food retail environments in Thailand and implications for the health and nutrition transition. Public Health Nutrition, $16,608-615$. 
Battersby, J., \& Peyton, S. (2016). The spatial logic of supermarket expansion and food access. In J. Crush \& J. Battersby (Eds.), Rapid urbanisation, urban food deserts and food security in Africa (pp. 33-46). Dordrecht: Springer.

Battersby, J., \& Watson, V. (Eds.). (2019). Urban food systems governance and poverty in African cities. London: Routledge.

Battersby, J., Marshak, M., \& Mngqibisa, N. (2016). Mapping the informal food economy in Cape Town, South Africa (HCP discussion paper no. 5). Cape Town: Hungry Cities Partnership.

Berger, M., \& van Helvoirt, B. (2018). Ensuring food secure cities: retail modernization and policy implications in Nairobi, Kenya. Food Policy, 79, 12-22.

Caesar, M., \& Crush, J. (2016). Food access and insecurity in a supermarket city. In J. Crush \& J. Battersby (Eds.), Rapid urbanisation, urban food deserts and food security in Africa (pp. 47-58). Dordrecht: Springer.

Crush, J., \& Battersby, J. (Eds.). (2016). Rapid urbanization, urban food deserts and food security in Africa. Dordrecht: Springer.

Crush, J., \& Frayne, B. (2018). The ‘supermarketization' of food supply and retail: private sector interests and household food security. In B. Frayne, J. Crush, \& C. McCordic (Eds.), Food and nutrition security in southern African cities (pp. 168-197). London: Routledge.

Crush, J., \& McCordic, C. (2017). The hungry cities food purchases matrix: household food sourcing and food system interaction. Urban Forum, 28, 421-433.

Crush, J., Skinner, C., \& Stulgaitis, M. (2017). Benign neglect or active destruction? A critical analysis of refugee and informal sector policy and practice in South Africa. African Human Mobility Review, 3, 751782.

Crush, J., Nickanor, N., \& Kazembe, L. (2019). Informal food deserts and household food insecurity in Windhoek, Namibia. Sustainability, 11(1), 37.

Dakora, E. (2012). Exploring the fourth wave of supermarket evolution: concepts of value and complexity in Africa. International Journal of Managing Value and Supply Chains, 3, 25-37.

Emongor, R. (2009). The impact of South African supermarkets on agricultural and industrial development in the Southern African development community. PhD Thesis, University of Pretoria, Pretoria.

Farina, E., Nunes, R., \& Monteiro, G. (2005). Supermarkets and their impacts on the agrifood system of Brazil: the competition among retailers. Agribusiness, 21, 133-147.

Frayne, B. (2005). Rural productivity and urban survival in Namibia: Eating away from home. Journal of Contemporary African Studies 23(1), 51-76

Frayne, B., Crush, J., \& McCordic, C. (Eds.). (2018). Food and nutrition security in southern African cities. London: Routledge.

Gorton, M., Sauer, J., \& Supatpongkul, P. (2011). Wet markets, supermarkets and the 'big middle' for food retailing in developing countries: evidence from Thailand. World Development, 39, 1624-1637.

Government of Namibia (2017). Namibia informal economy: case study report 2016/17. Windhoek: Ministry of Labour, Industrial Relations and Employment Creation, and Social Security Commission.

Huang, C., Tsai, K., \& Chen, Y. (2015). How do wet markets still survive in Taiwan? British Food Journal, $117,234-256$.

Humphrey, J. (2007). The supermarket revolution in developing countries: tidal wave or tough competitive struggle? Journal of Economic Geography, 7, 433-450.

Kambwale, J., Chisoro, C., \& Karodia, J. (2015). Investigation into the causes of small and medium enterprise failures in Windhoek, Namibia. Arabian Journal of Business and Management Review, 4, 80-109.

Kelly, M., Seubsman, S.-A., Banwell, C., Dixon, J., \& Sleigh, A. (2015). Traditional, modern or mixed? Perspectives on social, economic, and health impacts of evolving food retail in Thailand. Agriculture and Human Values, 32, 445-460.

Kennedy, G., Nantel, G., \& Shetty, P. (2004). Globalization of food systems in developing countries: a synthesis of country case studies (food and nutrition paper 83). Rome: FAO.

Louw, A., Chikazunga, D., Jordaan, D., \& Biénabe, E. (2007). Restructuring food markets in South Africa: dynamics within the context of the tomato subsector (Agrifood sector studies, Regoverning markets project). Pretoria: University of Pretoria.

Madevu, H., Louw, A., \& Kirsten, J. (2007). Mapping the competitive food chain for fresh produce: the case of retailers in Tshwane Metro, South Africa. International Food and Agribusiness Management Association 17th Annual World Symposium, Parma, June.

Miller, D. (2008). Food frontiers in Zambia: resistance and partnership in Shoprite's retail empire. At Issue ezine, 3, July 2008.

Minten, B. (2008). The food retail revolution in poor countries: is it coming or is it over? Economic Development and Cultural Change, 56, 767-789. 
Minten, B., \& Reardon, T. (2008). Food prices, quality, and quality's pricing in supermarkets versus traditional markets in developing countries. Review of Agricultural Economics, 30, 480-490.

Minten, B., Reardon, T., \& Sutradhar, R. (2010). Food prices and modern retail: the case of Delhi. World Development, 38, 1775-1787.

Nickanor, N. (2014). Food deserts and household food insecurity in the informal settlements of Windhoek, Namibia. PhD thesis, University of Cape Town, Cape Town.

Nickanor, N., Kazembe, L., Crush, J., \& Wagner, J. (2017). The supermarket revolution and food security in Namibia (urban food security series no. 26). Cape Town: AFSUN.

NSA (Namibia Statistics Agency) (2017). The Namibia labour force survey 2016 report, Windhoek: Namibia Statistics Agency.

Peyton, S., Moseley, W., \& Battersby, J. (2015). Implications of supermarket expansion on urban food security in Cape Town, South Africa. African Geographical Review 34, 36-54.

Reardon, T., \& Berdegué, J. (2002). The rapid rise of supermarkets in Latin America: challenges and opportunities for development. Development Policy Review, 20, 371-388.

Reardon, T., \& Gulati, A. (2008). The rise of supermarkets and their development implications (Discussion paper 00752). New Delhi: IFPRI.

Reardon, T., \& Hopkins, R. (2006). The supermarket revolution in developing countries: policies to address emerging tensions among supermarkets, suppliers and traditional retailers. European Journal of Development Research, 18, 522-545.

Reardon, T., Timmer, C., Barrett, C., \& Berdegué, J. (2003). The rise of supermarkets in Africa, Asia, and Latin America. American Journal of Agricultural Economics, 85, 1140-1146.

Reardon, T., Timmer, P., \& Berdegué, J. (2004). The rapid rise of supermarkets in developing countries: induced organizational, institutional and technological change in agrifood systems. Electronic Journal of Agricultural and Development Economics, 1, 168-183.

Schipmann, C., \& Qaim, M. (2011). Modern food retailers and traditional markets in developing countries: comparing quality, prices, and competition strategies in Thailand. Applied Economic Perspectives and Policy, 33, 345-362.

Seibes-Bock, B. (2004). A study of social constraints and economic survival strategies of female heads of households operating in the informal sector of Katatura, Windhoek, Namibia. MA thesis, University of Western Cape, Cape Town.

Si, Z., Scott, S., \& McCordic, C. (2016). Supermarkets, wet markets and food patronage in Nanjing, China (HCP discussion paper no. 4). Cape Town: Hungry Cities Partnership.

Skinner, C. (2019). Contributing and yet excluded? Informal food retail in African cities. In J. Battersby \& V. Watson (Eds.), Urban food systems governance and poverty in African cities. London: Routledge.

Skinner, C., \& Haysom, G. (2017). The informal sector's role in food security: a missing link in policy debates? (HCP discussion paper no. 6). Cape Town: Hungry Cities Partnership.

Skinner, C., \& Watson, V. (2018). The informal economy in cities of the global south: challenges to the planning lexicon. In G. Bhan, S. Srinivas, \& V. Watson (Eds.), The Routledge companion to planning in the global south (pp. 140-152). London: Routledge.

Suryadarma, D., Poesoro, A., Akhmadi, Budiyati, S., Rosfadhila, M., \& Suryahadi, A. (2010). Traditional food traders in developing countries and competition from supermarkets. Evidence from Indonesia. Food Policy, 35, 79-86.

Tacoli, C. (2017). Food (in) security in rapidly urbanizing, low-income contexts. International Journal of Environmental Research and Public Health, 14, 1554. https://doi.org/10.3390/ijerph14121554.

Vink, N. (2013). Commercialising agriculture in Africa: economic, social, and environmental impacts. African Journal of Agricultural and Resources Economics, 9, 1-17.

Weatherspoon, D., \& Reardon, T. (2003). The rise of supermarkets in Africa: implications for agri-food systems and the rural poor. Development Policy Review, 21, 333-355.

Publisher's Note Springer Nature remains neutral with regard to jurisdictional claims in published maps and institutional affiliations. 